\title{
Changes in Gene Expression in Canola Roots Induced by ACC-Deaminase-Containing Plant-Growth-Promoting Bacteria
}

\author{
Nikos Hontzeas, Saleema S. Saleh, and Bernard R. Glick \\ Department of Biology, University of Waterloo, Waterloo, ON N2L 3G1, Canada
}

Submitted 13 January 2004. Accepted 23 March 2003.

\begin{abstract}
The technique of RNA arbitrarily primed-polymerase chain reaction (RAP-PCR) was used to study changes in gene expression over time in canola roots treated with the 1-aminocyclopropane-1-carboxylate (ACC) deaminase-containing plant-growth-promoting bacterium Enterobacter cloacae UW4 and to compare the changes with those in a mutant of $E$. cloacae UW4 in which the ACC deaminase structural gene $a c d S$ was replaced by homologous recombination with acdS with an intentional knockout containing a tetracycline resistance gene. Genes that were either up- or down-regulated over a three-day period in canola plants treated with wild-type or mutant bacteria were isolated, cloned, and sequenced; all appeared to have high homology with Arabidopsis thaliana genes. The upregulated genes included a cell division cycle protein 48 homolog and a eukaryotic translation initiation factor 3 subunit 7 gene homolog. The downregulated genes included one encoding a glycine-rich RNA binding protein with a function in RNA processing or binding during ethylene-induced stress, which is expressed only in roots, and another gene thought to be involved in a defense signaling pathway. All RAPPCR results were verified using Northern blotting. These data, indicate that roots isolated from canola seeds treated with the ACC deaminase-producing $E$. cloacae UW4 upregulate genes involved in cell division and proliferation but down-regulate stress genes. This data is in agreement with a model in which ACC deaminase-containing plantgrowth-promoting bacteria reduce plant stress and induce root elongation and proliferation in plants, largely by lowering ethylene levels.
\end{abstract}

Plant-growth-promoting bacteria include a diverse group of free-living soil bacteria that can stimulate the growth of plants by one or more of a number of different mechanisms (Glick 1995). These bacteria may stimulate plant growth either directly or indirectly. Indirect stimulation of plant proliferation includes preventing phytopathogens from inhibiting plant growth and development (Holguin and Glick 2003; Robison et al. 2001; Wang et al. 2000); direct stimulation includes providing plants with compounds such as fixed nitrogen, phytohormones, or solubilized iron from the soil (Glick 1995; Glick et al. 1999).

Relatively recently, it was discovered that many plantgrowth-promoting bacteria contain the enzyme 1-aminocyclopropane-1-carboxylate (ACC) deaminase (Glick 1995;

Corresponding author: B. Glick; E-mail: glick@sciborg.uwaterloo.ca; Fax: +1.519.746.0614
Glick et al. 1999; Jacobson et al. 1994) and that this enzyme can cleave the ethylene precursor ACC to $\alpha$-ketobutyrate and ammonia and thereby lower the level of ethylene in developing or stressed plants. When ACC deaminase-containing plant-growth-promoting bacteria are bound to the seed coat or root of a developing seedling, they act as a sink for ACC, ensuring that plant ethylene levels do not become elevated to the point at which root growth is impaired (Glick et al. 1998). In addition, by lowering ethylene levels, ACC deaminase-containing plant-growth-promoting bacteria protect plants from the deleterious effects of numerous environmental stresses, including flooding (Grichko and Glick 2001), phytopathogens (Wang et al. 2000), metals (Burd et al. 1998, 2000; Grichko et al. 2000; Nie et al. 2002), drought (Mayak et al. 2004), and salt (Mayak et al. in press). The importance of the enzyme ACC deaminase in the functioning of the bacterium Enterobacter cloacae UW4 in plant growth promotion was recently demonstrated (Li et al. 2000). The ACC deaminase structural gene $(a c d S)$ from $E$. cloacae UW4 was replaced by homologous recombination with a tetracycline resistance gene inserted within the $a c d S$ coding region. Upon characterization of this AcdS minus $\left(\mathrm{AcdS}^{-}\right)$mutant, it was determined that both ACC deaminase activity and the ability to promote the elongation of canola roots under gnotobiotic conditions were greatly diminished $(\mathrm{Li}$ et al. 2000). This result is consistent with the previously postulated model (Glick et al. 1998) that suggests that a major mechanism utilized by plant-growth-promoting bacteria involves the lowering of plant ethylene levels, and hence, ethylene inhibition of plant proliferation by bacterial ACC deaminase. While it is clear that ACC deaminase-containing plantgrowth-promoting bacteria can promote the growth of a variety of plants under a range of conditions, the precise nature of the changes in plant gene expression that are caused by the bacterium remains to be elucidated. As a first step toward understanding how ACC deaminase promotes plant growth, in the present study, we have used the RNA arbitrarily primed PCR (RAP-PCR) technique to identify some ACC deaminase-responsive genes in canola (Brassica rapa) cv. Reward roots.

\section{RESULTS}

Effect of ACC deaminase-containing, plant-growth-promoting bacteria on canola root elongation.

Following five days in gnotobiotic growth pouches, canola roots produced from seeds treated with E. cloacae UW4 showed a significant increase in root length when compared with either the negative control or the $\mathrm{AcdS}^{-}$knockout mutant. 
The average root length of the E. cloacae UW4 treated plants was $98.0 \pm 11.3 \mathrm{~mm}$, compared with those treated with $E$. cloacae $\mathrm{UW} / \mathrm{AcdS}^{-}$, which were $61.0 \pm 10.3 \mathrm{~mm}$ (Fig. 1) and the roots of plants not treated with bacteria, which were $55.5 \pm$ $8.0 \mathrm{~mm}$ long. Thus, the roots of the E. cloacae UW4-treated canola were, on average, nearly twice as long as either untreated plants or plants treated with the mutant strain, confirming the relationship between ACC deaminase activity and plant root length (Li et al. 2000).

\section{Products of RAP-PCR.}

The concentration of total RNA extracted from canola roots treated with either wild-type or mutant E. cloacae UW4 was measured by spectrophotometry and then visualized on a $1 \%$ formaldehyde-aldehyde gel. To identify differentially expressed canola genes associated with the effects of ACC deaminase, RNA from roots treated with either E. cloacae UW4 or E. cloacae $\mathrm{UW}_{4} / \mathrm{AcdS}^{-}$and obtained five days after seed inbibition was used for RAP-PCR (Fig. 2). A total of six differentially expressed bands were successfully isolated and reamplified; four of these are shown in Figure 2. Even though there were other bands in the gel that appeared to be down-regulated, it was not possible to clone them. In order to identify the proteins that are encoded by these cDNA fragments, the bands were isolated and sequenced, and nucleotide sequences of the differentially expressed cDNAs were compared with sequences residing in the GenBank nucleotide and dbEST databases at the National Center for Biotechnology Information (NCBI). Four of the isolated cDNA fragments were similar to known sequences found in these databases, while RAP5 did

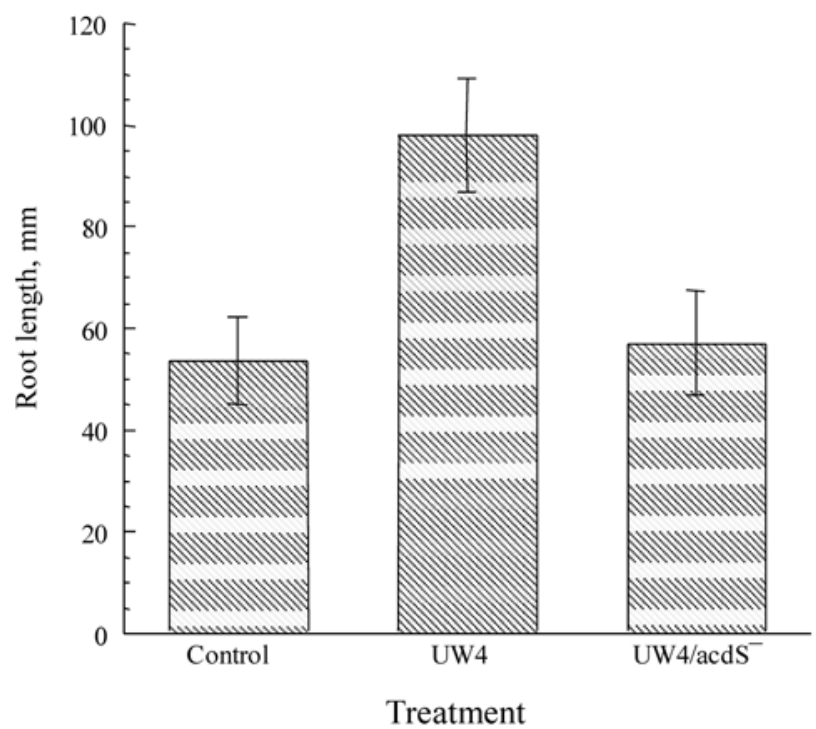

Fig. 1. Gnotobiotic root-length assay. Canola roots after five days of growth with either Enterobacter cloacae UW4 or with the E. cloacae 1-aminocyclopropane-1-carboxylate deaminase knockout mutant UW4/AcdS ${ }^{-}$. Error bars indicate standard error. not correspond to any significant extent to any known gene or protein, and RAP6 corresponded weakly with a probable retroelement polymerase polyprotein (Table 1). Based on amino acid sequence similarity, RAP1 was identified as a glycine-rich RNA-binding stress protein. At the amino acid level, RAP1 shares $68 \%$ identity to the stress protein from Brassica napus (Bergeron et al. 1993). An alignment of the amino acid sequences of the four known sequences with their nearest counterparts is shown in Figure 3. RAP2 was identified as a cell division cycle (cdc) 48 protein that showed $90 \%$ amino acid identity to the protein from Arabidopsis thaliana. RAP3 was identified as eukaryotic translation initiation factor $3 /$ subunit 7 . It showed a $69 \%$ amino acid identity with the comparable protein from A. thaliana. RAP4 was identified as a defense signaling pathway gene, which is homologous (70\% identity) to one found in A. thaliana.

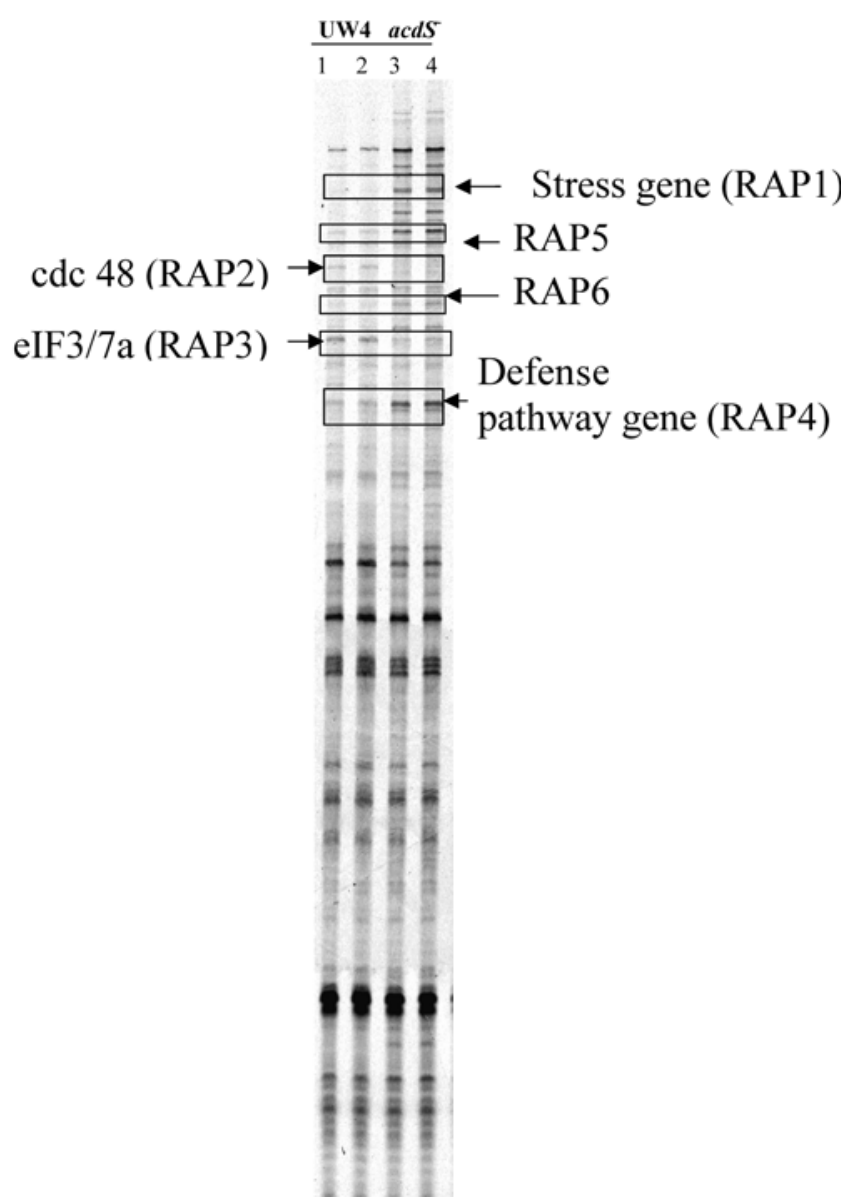

Fig. 2. Polyacrylamide gel showing RNA arbitrarily primed-polymerase chain reaction amplified cDNA fragments from canola roots. Genes differentially expressed and identified are boxed and labeled. Lanes 1 and 2, Canola roots treated with Enterobacter cloacae UW4. Lanes 3 and 4, canola roots treated with E. cloacae $\mathrm{UW}_{4} / \mathrm{AcdS}^{-}$.

Table 1. Differentially expressed genes that were identified using RNA arbitrarily primed (RAP)-polymerase chain reaction

\begin{tabular}{lccl}
\hline Fragment $^{\mathbf{a}}$ & Accession no. & Estimated size (bp) & \multicolumn{1}{c}{ Putative function } \\
\hline RAP1 (-) & AY406110 & 268 & Glycine-rich root-specific stress protein \\
RAP2 (+) & AY406108 & 647 & Cell division cycle 48 gene \\
RAP3 (+) & AY406109 & 365 & Eukaryotic translation initiation factor 3/subunit 7 gene \\
RAP4 (-) & AY406111 & 213 & Defense signaling pathway gene \\
RAP5 (-?) & CK927465 & 377 & Unknown function \\
RAP6 (-?) & CK937466 & 512 & Probable retroelement polymerase polyprotein \\
\hline
\end{tabular}

${ }^{a}(+)$ and (-) indicate genes up- or down-regulated, respectively, in canola treated with 1-aminocyclopropane-1-carboxylate deaminase-containing plantgrowth-promoting bacteria; ? indicates not determinable. 


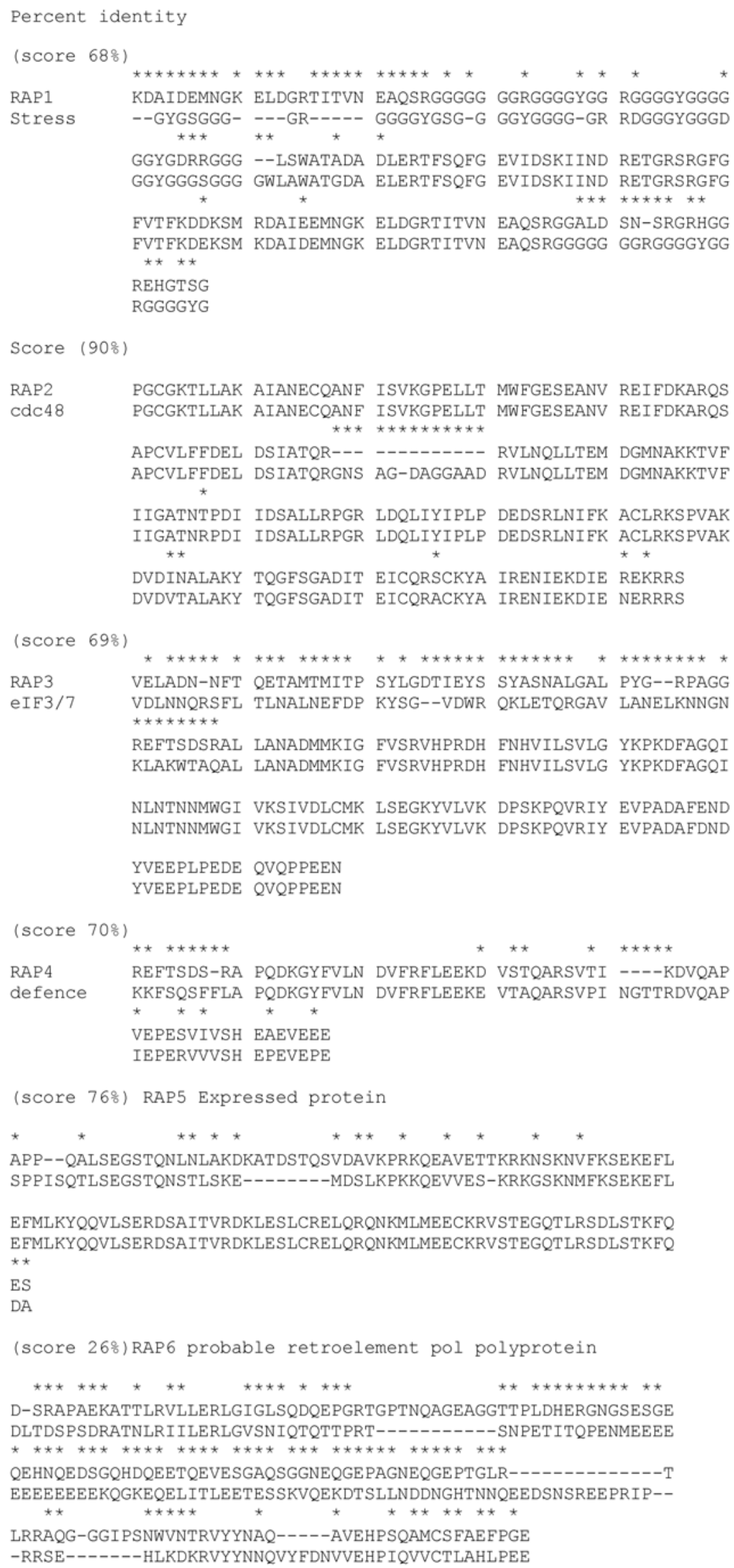

Fig. 3. Alignment of the amino acid sequences of RAP1, RAP2, RAP3, RAP4, RAP5, and RAP6 with known amino acid sequences. RAP1 was aligned with Brassica napus, whereas all others were aligned with Arabidopsis thaliana. An asterisk above a sequence indicates differences, and gaps are filled with bars. Score indicates percent identity. Alignment was done using ClustalW version 1.23. 
RNA blot hybridization analyses.

After sequencing and identifying the cDNAs, changes in the level of expression of the corresponding mRNAs due to the presence or absence of ACC deaminase were evaluated by Northern blot analyses. Total RNA from canola roots treated with either E. cloacae UW4 or E. cloacae $\mathrm{UW}^{\text {U/AcdS }}{ }^{-}$and harvested three or five days after seed imbibition was probed with the different cDNA products (i.e., RAP1, RAP2, RAP3, RAP4, RAP5, and RAP6). The expression of both RAP1 and RAP4 was down-regulated (Fig. 4A and B) in canola roots treated with ACC deaminase-containing bacteria, whereas expression of RAP2 and RAP3 was up-regulated (Fig. 4C and D).
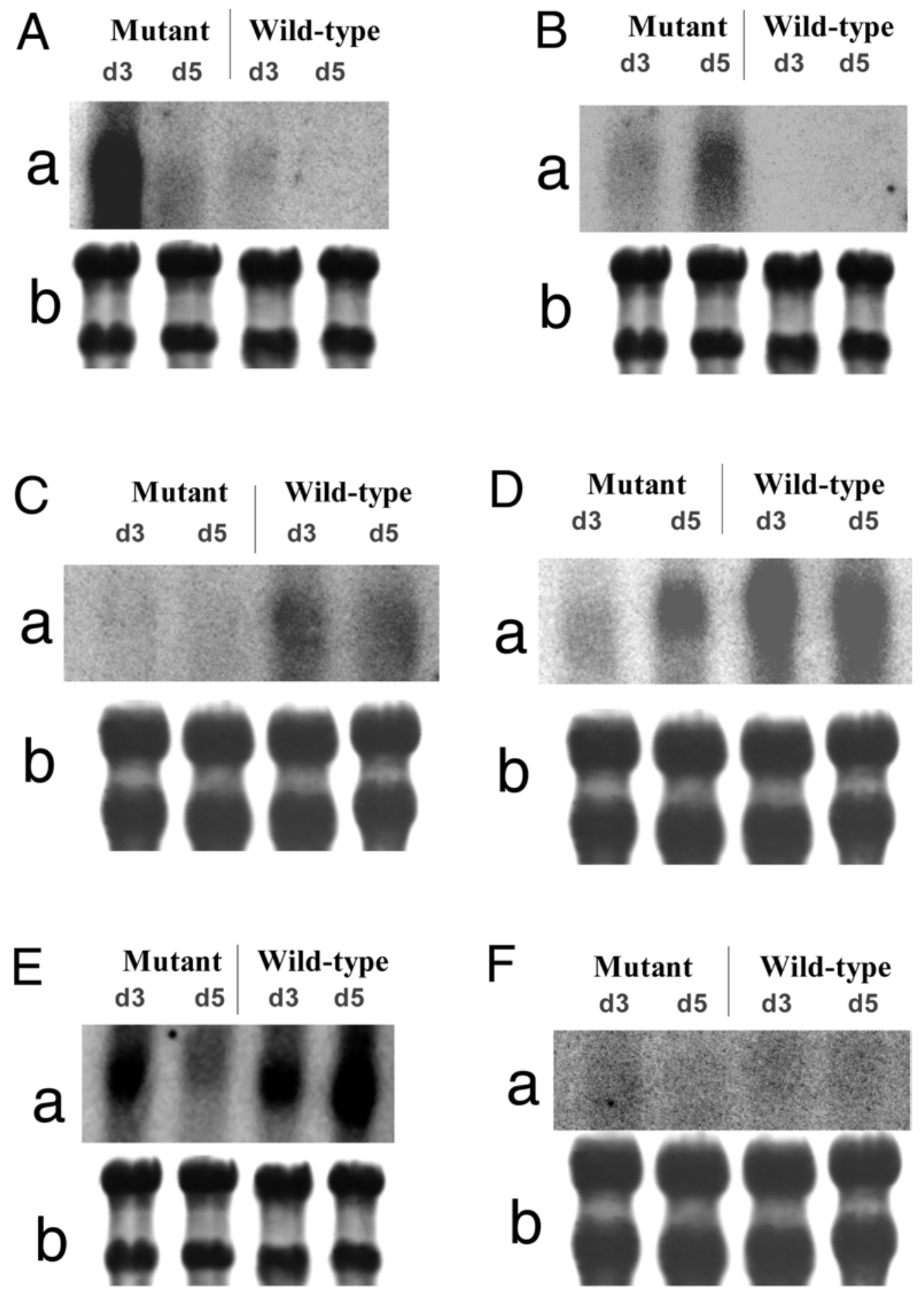

Fig. 4. Northern blots of genes putatively turned on or off by 1-aminocyclopropane-1-carboxylate deaminase. a, Northern blot of the RAP1 gene identified as encoding a glycine-rich root-specific stress protein. b, Northern blot of the RAP4 gene identified as encoding a SH2 binding defense signaling pathway gene. A, Canola roots were treated with either E. cloacae UW4 or UW4/AcdS ${ }^{-}$and were harvested 3 or 5 days posttreatment. B, A stained blot is shown immediately below the Northern blot. RNA ( $15 \mu \mathrm{g}$ in each lane) is from canola roots treated with $E$.cloacae UW4/AcdS ${ }^{-}$harvested at day 3 , canola roots treated with $E$.cloacae UW4/AcdS ${ }^{-}$harvested at day 5, canola roots treated with $E$.cloacae UW4 harvested at day 3, and canola roots treated with $E$ .cloacae UW4 harvested at day 5. C, Northern blot of the RAP2 gene identified as encoding a cell division cycle 48 gene. D, Northern blot of the RAP3 gene identified as encoding an eukaryotic translation initiation factor 3/subunit 7 gene. E, Northern blot of the RAP5 gene identified as an expressed protein. F, Northern blot of the RAP6 gene identified as a probable retroelement polymerase polyprotein. 
In addition, the expression of both RAP1 and RAP4 was time dependent. In E. cloacae $\mathrm{UW}^{-\mathrm{AcdS}^{-}}$treated canola roots, RAP1 mRNA was significantly more abundant in roots that were harvested after three days than those harvested after five days. Likewise, there was a faint signal for RAP1 in ACC deaminase-treated canola roots harvested after three days that was no longer evident in roots harvested after five days. While there are higher levels of RAP2 expressed in E. cloacae UW4treated canola than in plants treated with $E$. cloacae $\mathrm{UW}_{4} / \mathrm{AcdS}^{-}$, there is no significant difference in the expression of this mRNA between day 3 and day 5 canola roots treated with either E. cloacae UW4 or E. cloacae UW4/AcdS ${ }^{-}$. Similarly, there is a higher level of expression of RAP3 in $E$. cloacae UW4 treated canola than in that treated with E. cloacae $\mathrm{UW}_{4} / \mathrm{AcdS}^{-}$. There is no observable significant difference between day 3 and day 5 roots treated with E. cloacae UW4. However, there is a higher level of expression of RAP3 at day 5 in canola treated with $E$. cloacae $\mathrm{UW}$ /AcdS ${ }^{-}$than at day 3. RAP 5 showed strong expression in both E. cloacae UW4 and E. cloacae $\mathrm{UW} / \mathrm{AcdS}^{-}$, whereas RAP6 expression was very low in both $E$. cloacae UW4 and E. cloacae UW4/AcdS ${ }^{-}$.

\section{DISCUSSION}

In this study, we have examined some of the effects of ACC deaminase, present within the cytoplasm of a plantgrowth-promoting bacterium bound to the roots or seed coat, on gene expression in canola. RAP-PCR was used to compare the patterns of expressed mRNAs present in canola roots treated with ACC deaminase-containing plant-growth-promoting bacteria to those treated with an $\mathrm{AcdS}^{-}$knockout mutant. Several canola genes showed differential expression; however, only four corresponded to known genes. The differential expression of these four genes was subsequently confirmed by Northern blotting. RAP1 was identified as a glycine-rich root-specific stress gene, RAP2 as a cdc 48 gene, RAP3 as an eukaryotic translation initiation factor (eIF) 3 subunit, and RAP4 as a defense signaling pathway gene. Both RAP1 and RAP4 showed time-dependent expression, whereas RAP2 and RAP3 displayed mostly time-independent expression.

The root-specific stress gene encoded by RAP1 was first identified and characterized in canola (Brassica napus) by Bergeron and associates (1993). It contains a glycine-rich domain common to many RNA-binding proteins involved in plant stress responses. In addition, this gene is induced by ethylene-producing stresses, such as cold, wounding, flooding, and treatment with 2-chloroethylphosphonic acid, a compound that generates ethylene. Since ACC deaminasecontaining plant-growth-promoting bacteria affect plants by lowering their ethylene levels and alleviating some of the deleterious effects of ethylene-induced gene expression, it is not surprising that deletion of the ACC deaminase gene from E. cloacae UW4 results in a bacterium that no longer protects against the deleterious effects of ethylene. Thus, plants treated with wild-type E. cloacae UW4 do not need to express a root-specific stress gene that is expressed in plants treated with an E. cloacae UW4 mutant that does not have ACC deaminase activity. This result suggests that the ACC deaminase-containing E. cloacae UW4 helps to protect the seed and root system from the potentially deleterious effects of ethylene. Even though some ethylene is necessary for seed germination, higher levels of ethylene inhibit root growth. The addition of ACC deaminase-containing E. cloacae UW4 relieves some of the inhibitory effects of ethylene, observed in the significantly larger root lengths from canola (Brassica rapa cv. Reward) treated with these bacteria. This result is also in agreement with a model (Glick et al. 1998) that proposes the importance of the bacterial enzyme ACC deaminase in plant stress alleviation and, in addition, provides evidence that ACC deaminase-containing plant-growth-promoting bacteria down-regulate the expression of stress genes linked to the ethylene stress response.

Timmusk and Wagner (1999) previously showed that plants treated with the plant-growth-promoting bacterium Pseudomonas polymyxa and then exposed to either biotic or abiotic stress exhibited a strong inoculation-dependent increase in abundance in one particular mRNA. The corresponding gene was identified as ERD15, which was previously shown to be responsive to drought stress. Quantification of mRNA levels of several stress responsive genes indicated that $P$. polymyxa itself induced mild biotic stress. These authors suggested that biotic or abiotic stress could induce genes associated with plant defenses. Unlike treatment of a plant with $P$. polymyxa, a bacterium that does not show any significant ACC deaminase activity, treatment of canola with the ACC deaminase-containing plant-growth-promoting bacterium E. cloacae UW4 does not lead to an increase in other stress or a defense signaling pathway gene. For example, in the present study, we identified a defense signaling pathway gene that is down-regulated in ACC deaminase treated canola. In contrast, canola treated with the acdS knockout mutant show significant expression of this defense signaling pathway gene.

In addition to genes that are down-regulated, cdc 48 and eIF 3 genes are up-regulated in canola treated with an ACC deaminase-containing plant-growth-promoting bacterium, as compared with canola treated with the same bacterium containing an acdS knockout mutant. eIF 3 is the largest of the eIFs (Asano et al. 1997). It is a multiprotein complex of about $600 \mathrm{kDa}$ and is necessary for protein production. The upregulation of this gene in canola treated with an ACC deaminase-containing plant-growth-promoting bacterium can be explained by the fact that, when canola seeds are treated with E. cloacae UW4, the observed average root lengths after five days of growth are almost twice as long as when canola is treated with $E$. cloacae $\mathrm{UW}_{4} / \mathrm{AcdS}^{-}$. To achieve this additional root growth, more protein has to be produced; hence, it is reasonable to expect upregulation of one of the major transcripts required for plant root protein production. Similarly, the cdc 48 gene, which was previously isolated from Arabidopsis thaliana in which it was shown to be essential for cell division and growth, is highly expressed in the proliferating cells of the vegetative shoot and root (Feiler et al. 1995). In addition, it was recently demonstrated that certain Arabidopsis gene families, including ATPases and cell division cycle proteins, are involved in plant nutrition and root uptake systems and are necessary for plant survival (Maathuis et al. 2003). For E. cloacae UW4-treated roots to be twice as long as roots treated with $E$. cloacae $\mathrm{UW}^{4} / \mathrm{AcdS}^{-}$, the root cells require the upregulation of genes that are involved in root cell growth and proliferation.

By using the technique of RAP-PCR, we have demonstrated that, at the genetic level, the ACC deaminase-containing plantgrowth-promoting bacterium Enterobacter cloacae UW4 down-regulates a gene involved in ethylene-induced plant stress and up-regulates genes involved in plant growth. In addition, contrary to some plant-growth-promoting bacteria that do not contain ACC deaminase, canola treated with E. cloacae UW4 does not show an upregulation in a defense signaling pathway gene. This data lends further support to the previously proposed model that attempts to explain how ACC deaminasecontaining plant-growth-promoting bacteria facilitate the growth of plants (Glick et al. 1998). 


\section{MATERIALS AND METHODS}

\section{Bacterial strains.}

Enterobacter cloacae UW4 was isolated from the rhizosphere of reeds growing on the campus of the University of Waterloo based on its ability to utilize ACC as a sole source of nitrogen and to promote the growth of canola seedlings under gnotobiotic conditions (Glick et al. 1995). E. cloacae UW4 was originally identified as being Pseudomonas sp. UW4; however, this was subsequently changed to E. cloacae UW4 based on fatty acid analysis characterization of the bacterium (Shah et al. 1997). E. cloacae UW4/AcdS' is a genetic construct in which a tetracycline resistance gene was inserted into the coding region of the bacterial ACC deaminase gene (Li et al. 2000).

\section{Growth pouch assay.}

The protocol for assessing the effect of bacterial strains on the elongation of canola seedling roots followed a modification (Penrose and Glick 2003) of the method described by Lifshitz and associates (1987). Single colonies of bacterial strains were cultured in $5 \mathrm{ml}$ of tryptic soy broth (TSB) medium (supplemented with $15 \mu \mathrm{g} / \mathrm{ml}$ tetracycline for transconjugants) at $30^{\circ} \mathrm{C}$ for $24 \mathrm{~h}$ with shaking $(200 \mathrm{rpm})$. The bacterial cells were then centrifuged at $5,500 \times g$ at room temperature for $10 \mathrm{~min}$. The bacterial pellet was washed twice with $5 \mathrm{ml}$ of $0.85 \%$ $\mathrm{NaCl}$ before being resuspended in $0.85 \% \mathrm{NaCl}$ and adjusted to an absorbance of 0.3 to 0.4 at $600 \mathrm{~nm}$, prior to incubation with seeds.

Canola seeds (Brassica rapa cv. Reward), provided by G. Brown (Agrium, Inc., Saskatoon, Saskatchewan, Canada) and previously stored at $4{ }^{\circ} \mathrm{C}$, were surface-sterilized by soaking them in $1.5 \%$ sodium hypochlorite sodium (bleach) for 10 min. The seeds were subsequently rinsed with sterile distilled $\mathrm{H}_{2} \mathrm{O}$ five times and then incubated in either $5 \mathrm{ml}$ of $0.85 \%$ $\mathrm{NaCl}$, which acted as a blank control, or in the appropriate bacterial suspensions in $0.85 \% \mathrm{NaCl}$ for $1 \mathrm{~h}$ at room temperature $\left(22^{\circ} \mathrm{C} \pm 1{ }^{\circ} \mathrm{C}\right)$. The seeds were then put into growth pouches, as described by Penrose and Glick (2003). After five days, primary root lengths were measured and analyzed using a one-way analysis of variance in Instat version 2.01 for Macintosh (GraphPad Software, San Diego, CA, U.S.A.). Harvested roots and shoots were frozen in liquid nitrogen and stored at $-80^{\circ} \mathrm{C}$ until further analysis. Seeds that failed to germinate in 2 days after sowing were marked, and roots that subsequently developed from these seeds were not measured.

\section{RNA extraction.}

Frozen roots were ground, using a mortar and pestle, to a fine powder in liquid nitrogen. Total RNA for RAP-PCR and Northern blot hybridization was extracted using the plant RNeasy system (Qiagen, Missisauga, Ontario, Canada), following the manufacturer's instructions.

\section{RAP-PCR.}

RAP-PCR was carried out according to McClelland and Welsh (1994). A RAP-PCR primer set was obtained from Sigma Genosys (Oakville, Ontario, Canada). Each reverse transcription reaction contained $3 \mu \mathrm{g}$ of total RNA in a volume of $13 \mu \mathrm{l}$ of water. Two primers $(1 \mu \mathrm{l}$ of each), primer A1 (5'AATCTAGAGCTCCTCCTC-3') and primer A2 (5'-AATCTA GACCTCTCCTGG- $3^{\prime}$ ), each diluted to $25 \mu \mathrm{M}$, were added to the sample. The mixture was heated to $70^{\circ} \mathrm{C}$ for $10 \mathrm{~min}$ and subsequently chilled on ice. For reverse transcription, a master mix was made containing $4.5 \mu \mathrm{l}$ of $5 \times$ M-Muloney murine leukemia virus (MuL V) buffer (500 mM Tris- $\mathrm{HCl}, \mathrm{pH}$ 8.3, $0.1 \mathrm{M}$ $\mathrm{NaCl}, 1 \mathrm{mM}$ EDTA, $5 \mathrm{mM}$ dithiothreitol, $0.1 \%$ Triton $\mathrm{X}-100$,
$50 \%$ glycerol), $1 \mu \mathrm{l}$ of each of the four dNTPs $(25 \mu \mathrm{M}), 1 \mu \mathrm{l}$ RNase inhibitor, and $1 \mu \mathrm{M}$ M-MuL V reverse transcriptase (5 units $/ \mu \mathrm{l})$. All reagents were obtained from Fermentas, Inc. (Oakville, Ontario, Canada). The reverse transcription reaction was carried out at $37^{\circ} \mathrm{C}$ for $1 \mathrm{~h}$, followed by inactivation of the transcriptase by heating at $95^{\circ} \mathrm{C}$ for $5 \mathrm{~min}$. The cDNA obtained was diluted 1:10 with water, and to $5 \mu \mathrm{l}$ of the diluted cDNA, $1 \mu \mathrm{l}$ of primer A $1(25 \mu \mathrm{M})$ and $1 \mu \mathrm{l}$ of primer A2 $(25$ $\mu \mathrm{M}), 1 \mu \mathrm{l}$ of dNTPs $(25 \mu \mathrm{M}), 1 \mu \mathrm{l}$ of Taq polymerase (5 units), $5 \mu \mathrm{l}$ of Taq polymerase buffer $(\times 10)$ was added. All reagents were obtained from Fermentas, Inc. RAP-PCR was carried out using the following conditions: denaturation at $94^{\circ} \mathrm{C}$ for 1 min, annealing at $36^{\circ} \mathrm{C}$ for $5 \mathrm{~min}$, extension at $72^{\circ} \mathrm{C}$ for $5 \mathrm{~min}$ in an MJ Instruments PTC-100 thermocycler (Waltham, MA, U.S.A.). This was followed by 39 cycles of denaturation at $94^{\circ} \mathrm{C}$ for $1 \mathrm{~min}$, annealing at $35^{\circ} \mathrm{C}$ for $2 \mathrm{~min}$, and extension at $72^{\circ} \mathrm{C}$ for $2 \mathrm{~min}$. Subsequently, the cDNA products were labeled with Cy-5 primer ( $5^{\prime}$-AATCTAGAGCTC- $3^{\prime}$ ) by adding 1 unit of exo ${ }^{-}$Klenow fragment (Fermentas) for $2 \mathrm{~h}$ at $37^{\circ} \mathrm{C}$. The labeled products were subsequently run in a vertical DNA $1.4 \%$ polyacrylamide sequencing gel for $4 \mathrm{~h}$ at $2,000 \mathrm{~V}$. The gel was visualized using a Storm 860 optical scanner (Molecular Dynamics, Sunnyvale, CA, U.S.A.); differentially expressed bands were excised from the gel, and the cDNA products were gel-isolated using the Qiaxx II kit from Qiagen (Oakville, Ontario, Canada).

\section{Cloning, sequencing and analyses.}

cDNA products were cloned into the pGEM-T easy vector system from Promega (Mississauga, Ontario, Canada). The cloned partial cDNA sequences were sequenced using the dyeterminator cycle sequencing method on an ABI Prism model 377 system (Applied Biosystems, Foster City, CA, U.S.A.). The nucleotide sequences obtained were submitted to the NCBI server for BLASTN and BLASTX searches against nucleotide and protein sequences available in various databases.

\section{RNA blot hybridization.}

Total RNA $(20 \mu \mathrm{g})$ was size-separated on a formaldehyde denaturing $1.2 \%$ agarose gel according to Sambrook and associates (1989). RNA was capillary transferred to a positively charged nylon membrane (Roche, Quebec, Canada), using 20× $\mathrm{SSC}(1 \times \mathrm{SSC}$ is $0.15 \mathrm{M} \mathrm{NaCl}$ plus $0.015 \mathrm{M}$ sodium citrate) as the transfer medium. RNA was fixed to the membrane by UVcrosslinking for 3 min (UV Stratalinker 2400; Stratagene, La Jolla, CA, U.S.A.). Membranes were probed using cDNA probes labeled with $\alpha-32 \mathrm{P}-\mathrm{dCTP}$ (Amersham, Toronto). Membranes were probed overnight and afterwards washed two times at room temperature for $15 \mathrm{~min}$ and then one time at $65^{\circ} \mathrm{C}$ for 30 min with $5 \times$ SSC and $0.1 \%$ sodium dodecyl sulfate (SDS). The washed membrane was visualized using a Storm 860 optical scanner (Molecular Dynamics).

For subsequent reprobing, the membrane was stripped of bound probe by boiling three times in $0.1 \% \mathrm{SDS}$, for $15 \mathrm{~min}$ and then reused.

\section{ACKNOWLEDGMENTS}

N. Hontzeas was the recipient of a Natural Science and Engineering Research Council of Canada (NSERC) graduate scholarship. This work was funded by a grant from NSERC to B. R. Glick.

\section{LITERATURE CITED}

Asano, K., Kinzy, T. G., Merrick, W. C., and Hershey, J. W. B. 1997. Conservation and diversity of eukaryotic translation initiation factor eIF3. J. Biol. Chem. 272:1101-1109.

Bergeron, D., Beauseigle, D., and Bellemare, G. 1993. Sequence and ex- 
pression of a gene encoding a protein with RNA-binding and glycinerich domains in Brassica napus. Biochim. Biophys. Acta. 1216:123-5.

Burd, G. I., Dixon, D. G., and Glick, B. R. 1998. A plant growth promoting bacterium that decreases nickel toxicity in plant seedlings Appl. Environ. Microbiol. 64:3663-3668.

Burd, G. I., Dixon, D. G., and Glick, B. R. 2000. Plant growth-promoting bacteria that decrease heavy metal toxicity in plants. Can. J. Microbiol. 46:237-45.

Feiler, H. S., Desprez, T., Santoni, V., Kronenberger, J., Caboche, M., and Traas, J. 1995. The higher plant Arabidopsis thaliana encodes a functional CDC48 homologue which is highly expressed in dividing and expanding cells. EMBO (Eur. Mol. Biol. Organ.) J. 14:5626-5637.

Glick, B. R. 1995. The enhancement of plant growth by free-living bacteria. Can. J. Microbiol. 41:109-117.

Glick, B. R., Karaturovíc, D. and Newell, P. 1995. A novel procedure for rapid isolation of plant growth-promoting rhizobacteria. Can. J. Microbiol. 41: 533-536.

Glick, B. R., Penrose, D. M., and Li, J. 1998. A model for the lowering of plant ethylene concentrations by plant growth-promoting bacteria. J. Theor. Biol. 190:63-68.

Glick, B. R., Patten, C. L., Holguin, G., and Penrose, D. M. 1999. Biochemical and genetic Mechanisms Used by Plant Growth Promoting Bacteria. Imperial College Pres, London.

Grichko, V. P., and Glick, B. R. 2001. Amelioration of flooding stress by ACC deaminase-containing plant growth-promoting bacteria. Plant Physiol.Biochem. 39(1):11-17.

Grichko, V. P., Filby, B., and Glick, B. R. 2000. Increased ability of transgenic plants expressing the bacterial enzyme ACC deaminase to accumulate $\mathrm{Cd}, \mathrm{Co}, \mathrm{Cu}, \mathrm{Ni}, \mathrm{Pb}$, and $\mathrm{Zn}$. J. Biotechnol. 81:45-53.

Holguin, G., and Glick, B. 2003. Transformation of Azospirillum brasilense $\mathrm{Cd}$ with an ACC deaminase gene from Enterobacter cloacae UW4 fused to the $\operatorname{Tet}^{\mathrm{r}}$ gene promoter improves its fitness and plant growth promoting ability. Microb. Ecol. 4:122-133.

Jacobson, C. B., Pasternak, J. J., and Glick, B. R. 1994. Partial purification and characterization of 1-aminocyclopropane-1-carboxylate deaminase from the plant growth promoting rhizobacterium Pseudomonas putida GR12-2. Can. J. Microbiol. 40:1019-1025.

Li, J., Ovakim, D. H., Charles, T. C., and Glick, B. R. 2000. An ACC deaminase minus mutant of Enterobacter cloacae UW4 no longer promotes root elongation. Curr. Microbiol. 41:101-105.

Lifshitz, R., Kloepper, J. W., Kozlowski, M., Simonson, C., Carlson, J., Tipping, E. M., and Zaleska, I. 1987. Growth promotion of canola (rapeseed) seedlings by a strain of Pseudomonas putida under gnotobiotic conditions. Can. J. Microbiol. 33:390-395.

Maathuis, F. J. M., Filatov, V., Herzyk P., Krijger, G. C., Axelsen, K. B. Chen, S., Green, B. J., Li, Y., Madagan, K. L., Sánchez-Fernández, R., Forde, B. G., Palmgren, M. G., Rea, P. A., Williams, L. E., Sanders, D., and Amtmann, A. 2003. Transcriptome analysis of root transporters reveals participation of multiple gene families in the response to cation stress. Plant J. 35:675-692.

Mayak, S., Tirosh, T., and Glick, B. R. 2004a. Plant growth-promoting bacteria that confer resistance to water stress in tomato and pepper Plant Sci. 166:525-530

Mayak, S., Tirosh, T., and Glick, B. R. Plant growth-promoting bacteria that confer resistance in tomato and pepper to salt stress. Plant Physiol. Biochem., in press.

Nie. L., Shah, S., Rashid, A., Burd, G. I., Dixon, D. G., and Glick, B. R. 2002. Phytoremediation of arsenate contaminated soil by transgenic canola and the plant growth-promoting bacterium Enterobacter cloacae CAL2. Plant Physiol. Biochem. 40:355-361.

Penrose, D. M., and Glick, B. R. 2003. Methods for isolating and characterizing ACC deaminase-containing plant growth-promoting rhizobacteria. Physiol. Plant. 118:10-15.

Robison, M. M., Shah, J., Tamot, B., Pauls, K. P., Moffat, B. A., and Glick, B. R. 2001. Reduced symptoms of verticillium wilt in transgenic tomato expressing a bacterial ACC deaminase. Mol. Plant Pathol. 2:135-145.

Sambrook, J., Fritsch, E. F., and Maniatis, T. 1989. Molecular Cloning: A Laboratory Manual. 2nd ed. Cold Spring Harbor Laboratory Press, Cold Spring Harbor, NY, U.S.A.

Shah, S., Li, J., Moffatt, B. A. and Glick, B. R. 1997. ACC deaminase genes from plant growth promoting rhizobacteria. Pages 320-324 in: Plant Growth-Promoting Rhizobacteria. Present Status and Future Prospects. A Ogoshi, K. Kobayashi, Y. Hemma, F. Kodema, N. Kondo and S. Akino. eds. Organization for Economic Cooperation and Development, Paris.

Timmusk, S., and Wagner, E. G. H. 1999. The plant-growth-promoting rhizobacterium Paenibacillus polymyxa induces changes in Arabidopsis thaliana gene expression: A possible connection between biotic and abiotic stress responses. Mol. Plant-Microbe Interact. 12:951-959.

Wang, C., Knill, E., Glick, B. R., and Defago, G. 2000. Effect of transferring 1-aminocyclopropane-1-carboxylic acid (ACC) deaminase genes into Pseudomonas fluorescens strain $\mathrm{CHA} 0$ and its gacA derivative CHA96 on their growth-promoting and disease-suppressive capacities. Can. J. Microbiol. 46:898-907. 